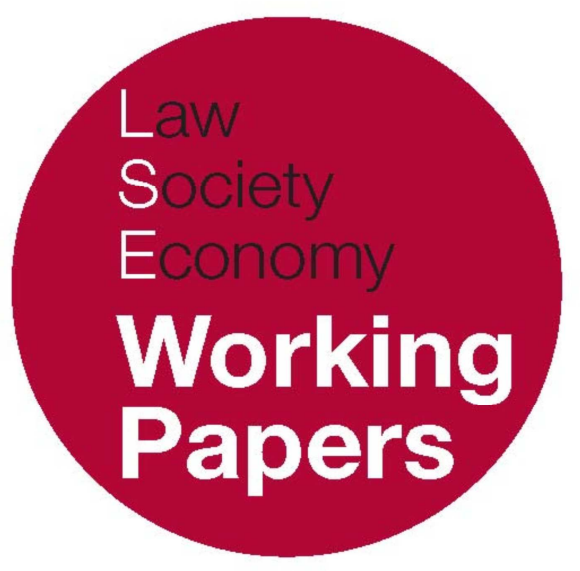

\title{
Theorising International Environmental Law
}

\author{
from The Oxford Handbook of International Legal Theory \\ (Florian Hoffmann and Anne Orford, eds, Oxford UP, \\ forthcoming 2014)
}

\section{Stephen Humphreys and Yoriko Otomo}

LSE Law, Society and Economy Working Papers 9/2014 London School of Economics and Political Science

Law Department

This paper can be downloaded without charge from LSE Law, Society and Economy Working Papers at: www.lse.ac.uk/collections/law/wps/wps.htm and the Social Sciences Research Network electronic library at: http:/ / ssrn.com/abstract=2385836.

(C) Stephen Humphreys and Yoriko Otomo. Users may download and/or print one copy to facilitate their private study or for non-commercial research. Users may not engage in further distribution of this material or use it for any profit-making activities or any other form of commercial gain. 


\title{
Theorising International Environmental Law
}

\author{
Stephen Humphreys and Yoriko Otomo*
}

\begin{abstract}
This paper, part of a larger work on international law theory, sketches some early lines of inquiry towards a theoretical understanding of international environmental law.

As the body of international law regulating human interaction with the natural world, one might expect this branch of law to be a cornerstone of the international system. Yet in practice, international environmental law's reach is strikingly circumscribed. Little of the governance of natural resources, for example, is 'environmental'. Subsisting at the periphery, environmental law focuses on conserving particular (rare, exotic) species and 'ecosystems', and curbing certain kinds of pollution. Its principles are vague, peppering the margins of rulings within other judicial fora: it is quintessential soft law.

In this paper, we suggest that international environmental law's dilemmas are due to two competing heritages. On one hand, this law enshrines the peculiar pantheism of the European romantic period, positing the 'natural world' as sacred, inviolable, redemptive. On the other, its main antecedents are found in colonial era practices, which provided the data for the earliest environmental science and a laboratory for prototypical attempts at conservation and sustainable development. Caught between irreconcilable demands, international environmental law struggles today to avoid utopian irrelevance or nugatory paralysis.
\end{abstract}

\footnotetext{
* Respectively Associate Professor of International Law, London School of Economics, and Lecturer in Law, SOAS. This paper was drafted as a contribution to Florian Hoffmann and Anne Orford, eds, The Oxford Handbook of International Legal Theory, Oxford UP (forthcoming 2014). It is published with the permission of Oxford University Press. The paper represents an early step in a larger project. Versions of this paper were presented in York in March 2013, Amsterdam in May 2013, and, in near-present form, at the Lauterpacht Centre for International Law in the University of Cambridge on 22 November 2013. Our thanks to the participants at those events for helpful comments and questions.
} 
'TT] he idea of nature contains, though often unnoticed,

an extraordinary amount of human history'

Raymond Williams, 'Ideas of Nature' (1972)

\section{INTRODUCTION}

International environmental law raises a paradox. As the body of international law that regulates 'the environment', one might expect international environmental law to be a cornerstone of the international legal system. What, after all, is more fundamental to the constitution of the world than the human relation to nature? And yet it is striking how little international environmental law does, in fact, regulate. The global food regime, for example, mostly escapes it: agricultural practices and the slaughter of animals for food (or otherwise) are largely beyond its remit. Those phenomena referred to as 'natural resources' are generally managed under separate headers or, more often, private arrangements.

Instead we find international environmental law at the margins of these concerns, dealing with the 'conservation' of certain plants, certain animals, certain 'ecosystems'.1 Marginalia complemented by effluvia: as a matter of treaty law, international environmental law also aims to curb certain forms of pollution. ${ }^{2}$ In keeping with this general peripherality, the key environmental cases have arisen at the edges of other bodies of law. ${ }^{3}$ International environmental law is generally characterised as quintessential 'soft law': general principles and aspirational treaties with weak or exhortatory compliance mechanisms, often dependent on other disciplines altogether-science and economics-for direction and legitimacy. ${ }^{4}$ At the same time, the problems it is called upon to deal with are immense, frequently catastrophic, and global in nature: climate change, species extinction, increasing desert, disappearing rainforest. ${ }^{5}$

Despite or because of all this, international environmental law, more than most bodies of law, has many of the trappings of a faith. It derives its effect largely from its affect: international environmental law stages a kind of global moral authority, premised on an aesthetic ideal and an ethical disquiet. For its acolytes, its essence lies in a series of general principles: the do-no-harm principle, the precautionary principle, the polluter pays principle, the principles of equity and

\footnotetext{
${ }^{1}$ E.g., Convention on International Trade in Endangered Species (1973): Convention on Biological Diversity (1992).

2 E.g., Convention on Long-Range Transboundary Air Pollution (1979), the London Convention (1972), the Basel Convention (1989), UN Framework Convention on Climate Change (1992).

3 At the WTO: EC-Asbestos, US_Gasoline, US - Shrimp, EC-Hormones, Canada_Autos, EC-Biotech, EC-Retreaded Tyres; at the ECtHR: López. Ostra v. Spain, Öneryuldız. v. Turkey, Budayeva and Ors. v. Russia, Fadeyeva v. Russia; at the ICJ: the Gabcikovo-Nagymaros and Pulp Mills cases.

${ }^{4}$ E.g., Sands and Peel (2012), ch.5; Birnie et al. (2009), ch.4.

5 UN Convention to Combat Desertification (1992); International Tropical Timber Agreement (2006).
} 
'common but differentiated responsibilities', and of course the über-principle: 'sustainable development'. Interposed into the practices of international commerce and diplomacy, as its advocates demand, these principles promise radical reshaping of 'business-as-usual'. In vain, it seems: for, again more than most areas of international law, this is law crying in the wilderness.

The little sustained theoretical attention this body of law has attracted to date has concentrated in the main on its relationship with property law-posited as one of mutual constraint. ${ }^{6}$ While we touch on this important question, in this chapter we direct our principal focus elsewhere, situating international environmental law with regard to the constituent conceptual elements that generate its specific energy and propel its contradictions today. We find this energy and tension in two principal historical sources: first, the romantic movement of the late eighteenth/early nineteenth centuries; second the evolution of colonial governance practices through to the mid-twentieth century.

As to the first of these, it is through romantic philosophy and poetry that contemporary ideas about 'nature' became firmly established. This influential movement, as political as it was artistic, implanted lasting notions of the beauty of 'unspoilt' wilderness, imbued with a profound moral significance, that have endured to the present and provide the ideational backdrop specific to this body of international law, as we will show. In this venture, we will be aided by what is by now a significant body of work investigating the intellectual origins of modern environmentalism. ${ }^{7}$

As to the second source, from the outset, administrators in colonial territories found themselves grappling with concrete questions on the management of territorial, natural, and livestock resources. These included: a demand for immediate returns on the significant investments of colonial enterprise; a belated preservationist impulse emerging from the burgeoning aestheticisation of colonial landscapes; and a drive to ensure sustainable long-term access to the resources that increasingly fuelled a global economy. In examining the competing discourses of colonial resource management, we will be drawing on a second literature that has recently flowered: that of environmental history. ${ }^{8}$

In this chapter, therefore, we will tentatively open up some new theoretical perspectives on a body of law that (perhaps surprisingly for such an epistemologically rich subject) has been subjected to little theoretical speculation. ${ }^{9}$ After this introduction, we begin by posing a question of terminology-why 'international environmental law'? Then, following sections on the romantics and the colonials, we return to the present in our conclusion to show how international environmental law's origins in the confluence of the romantic and

\footnotetext{
${ }^{6}$ Coyle and Morrow (2004).

7 Bate (1991); Buell (1995); Coupe, ed. (2000); Garrard (2012); Oelschlager (1993); Thomas (1983); Williams (1973).

8 Grove (1995); Beinart and Hughes, eds (2007); Hutchings (2009); Walsham (2011); Thorsheim (2006); Crosby (1986).

${ }^{9}$ But see the contributions to Philippopolous-Mihalopolous, ed. (2011).
} 
the colonial explains the apparent mismatch between its ambitious stated objectives and its muted regulatory provisions - and how this tension continues to inform its functioning today.

\section{WHY 'INTERNATIONAL ENVIRONMENTAL' LAW?}

'International environmental law' is not, at first glance, a body of law dealing with an 'international environment' (for what would this be?) but a branch of 'international law' dealing with 'the environment'. After all, an 'environment' presumes a specific locality, a surround. ${ }^{10}$ 'Environmental law' would then be the law relevant to, in the words of the OED, '[ $t$ ]he physical surroundings or conditions in which a person or other organism lives, develops, etc. [...], ${ }^{11}$ i.e., a somewhere. As such, it enters a context already steeped in law: at the margins of a property law whose excesses it potentially curtails and whose conflicts it mediates. ${ }^{12}$ Abstracted to the international plane, however, 'environmental law' is unavoidably delocalised - the law now relates to 'the environment' in a second sense provided by the OED: 'the natural world or physical surroundings in general [...] especially as affected by human activity' - the law of that which 'surrounds' us, humankind: our (shared/collective) surround. ${ }^{13}$ This abstracted universal 'environment' is concretised in international legal instruments such as those dealing with climate change (the atmosphere as a global commons) or biodiversity (the preservation of the world's species as a moral imperative): the 'earthly environment', as the 1971 Stockholm Declaration on the Human Environment put it. ${ }^{14}$

International environmental law is, then, a body of law dealing with 'nature', as distinct from 'culture' or the 'human'. The sobriquet 'environment' is relatively new, dating from the 1960s or thereabouts. But what is altered, what is masked, in the substitution of 'environment' for 'nature'? The obvious answer-but not, we will suggest, the whole one-is that the term 'nature' carries too much baggage. Whereas 'nature' presumably includes humankind; 'environment' apparently does not. And whereas nature (Latin: natura, 'essence') lends itself easily to contradictory doxa (both good and evil, creation and destruction, may be 'natural'), 'environment' is more muted, more technocratic. 'Nature' has, moreover, already been the site of countless battles—religious, political, scientific, economic - many of which are still unresolved today.

\footnotetext{
10 'The traditional imaging of the environment [is] as a thing that turns (French virer) around a stable point (a distilled sense of pure humanity)'. Philippopolous-Mihalopolous (2011), 7.

11 OED (2011), entry 63089. This usage dates to the 1830s, later popularised by Charles Darwin.

12 Coyle and Morrow (2004), Introduction.

13 OED (2011), entry 63089. This usage is dated to 1948.

14 Preamble to the Stockholm Declaration (1971).
} 
This in view, a first-obvious but important-observation is that international environmental law articulates a regulatory interface with 'nature' not only in its material existence but also in its metaphysical insistence. A second observation is that with international environmental law we are not dealing with 'natural law'. At first glance, these appear to be two far distant bodies of law. But clearly something significant is at work in the move from a law (extending to a law of nations) subject to something called 'nature', and a law that seems intended instead to subject 'nature'. Viewed from this angle, there is a historical turn (a modern turn, a hubristic turn) in which nature is dethroned or mastered.

The story of this 'turn' is familiar, and goes something like this. In Europe, Christianity implants itself within a richly pagan natural world, replete with spirits, fairies and demigods that are incrementally rolled and cajoled into Christcompatible stories or purged altogether. ${ }^{15}$ The human in the Christian universe was still part of nature (albeit a superior part). The natural world tout court was God's domain, unified and rational, and God-Right Reason, reflected in Man, immanent in Nature-was the uncontroversial source of law well into the Reformation. ${ }^{16}$ There is thus a debatable divide between man and nature, but plenty of scope for its transgression, for nature to act or react in sympathy with human affairs, for man to revert, return or subsume into nature. ${ }^{17}$

It is possible to trace three broad articulations of the human-natural relation across the subsequent (early modern) period. First there is the presumption of man's God-given dominion over plants and animals, as expounded in the bible and relied upon by the Dominicans in the pre-Reformation era and, most pointedly, the Puritans afterwards. ${ }^{18}$ This doctrine gave rise to the tenacious belief that there were few 'natural' bounds on human exploitation of the earth's resources-'the brute creation are [man's] property, subservient to his will and for him made'19other than those imposed in civil society to avoid war. An ideology of ('natural') human dominion over the ('natural') world gains force during-indeed on some accounts actively underpins - the Reformation, appearing in a stronger form in, for example, Hugo Grotius' writing, weaker in Thomas Hobbes'-together with the cognate notion of sovereignty itself. ${ }^{20}$

A second, somewhat countervailing, view of the human-natural relation, also derived from the bible, was the doctrine of usufruct, with which the pre-modern Franciscans resisted the predations and hubris of 'natural dominion'. ${ }^{21}$ This

\footnotetext{
15 Walsham (2011), ch.1.

${ }^{16}$ Humphreys (2010), ch.3; Tuck (1979), esp. 17-31 and ch.3.

17 Thomas (1984), 75.

${ }^{18}$ Genesis i, 28; Tuck (1979), ch.1 (on the Dominicans); Thomas (1984), 17-25 (on the Puritans).

${ }_{19}$ Thomas (1984), 22, citing the poet-hunter William Somerville (1735).

${ }^{20}$ See generally Tuck (1979) and esp. chs 3\&6; Grotius (1625), bk.2, ch.2. Hobbes (1651), ch.14: in the state of nature 'every man has a right to everything', albeit moderated (ch.15) by a right of equity and, therefore, usage 'proportionably to the number of them that have the right'; in civil society, however, there are no obvious restrictions on the right of the sovereign usage of natural resources (ch.18) except where the subject retains a right of resistance in cases of necessity (ch. 21). See also Coyle and Morrow (2004), 11-35.

21 Tuck (1979), 20-24.
} 
doctrine reappears in diluted form in the post-Reformation era in the guise of stewardship, the admonition to act, as English Chief Justice Matthew Hale put it in 1677, as 'steward, villicus, bailiff or farmer over this goodly farm' of the earth. ${ }^{22}$ It is an approach to the natural world that reaches us today in various configurations of the notion of trusteeship. ${ }^{23}$

With the enlightenment, however-comprising the third view-nature (Greek: physis) becomes an object of inquiry with empirically discoverable 'laws of nature' (physics), quite distinct from human laws. Around the same time, nature, the 'state of nature', is counterposed to the human, the civilised-albeit with very different inflections in the principal exponents, Thomas Hobbes, John Locke, and Jean-Jacques Rousseau. ${ }^{24}$ Not long afterwards, as a matter of historical fact, modernisation (urbanisation, secularisation, the industrial revolution) alters the experience of nature: it becomes something 'out there', in the 'country'. ${ }^{25}$ From whence will emerge a romantic sensibility that values nature intrinsically-as an object of aesthetic contemplation and site of an authentic human experience of the divine-to which we will turn presently.

Throughout all this, the relationship between 'humanity' and 'nature' undergoes significant contortion and reconstruction, both as a historical and as a conceptual matter. Keith Thomas's 1982 Man and the Natural World is the outstanding account of the former; Raymond Williams's essay of 1972, 'Ideas of Nature', is perhaps the most succinct inquiry into the latter. In his exhaustive account of the success of the early naturalists in removing the superstitions and beliefs attaching to plants and animals, ${ }^{26}$ Thomas remarks:

[B]y eroding the old vocabulary, with its rich symbolic overtones, the naturalists completed their onslaught [...] In place of a natural world redolent with human analogy and symbolic meaning, and sensitive to man's behaviour, they constructed a detached natural scene to be viewed and studied by the observer from the outside, as if peering through a window in the secure knowledge that the objects of contemplation inhabited a separate realm $[\ldots]^{27}$

Raymond Williams tells a similar story of a secular drive towards the separation between man and nature. ${ }^{28}$ The 'problem' arises, Williams says, because 'nature' is effectively sliced up into very different entities depending on how it is used: part of it reappears in the form of products (coal), another part as by-products (slag:

\footnotetext{
22 Hale (1677), 370.

${ }^{23}$ For an influential example, Weiss (1989).

24 Williams (1980), 76; Coyle and Morrow (2004).

25 Williams (2011), 1-2.

${ }^{26}$ This takes place, on Thomas's account, in part by replacing vernacular nicknames (such as 'Motherdee [...] so known because it would kill the parents of the child who picked it') with the Latin binomials introduced by the Swedish botanist Carl Linnaeus (so: silene dioica). Thomas (1984), 75.

27 Thomas (1984), 89.

${ }^{28}$ Williams (1980), 83.
} 
waste; pollution), while another part takes on the attraction of a pastoral scene (the pristine meadow aboveground). ${ }^{29}$ For Williams, the accumulating 'interaction' necessitates a deepening ideological split between 'human nature' and 'nature'and further, within nature itself: removing 'coal-bearing from heather-bearing, downwind from upwind'. ${ }^{30}$ Williams concludes:

As the exploitation of nature continued, on a vast scale $[\ldots]$ the people who drew the most profit from it went back [...] to an unspoilt nature, to the purchased estates and the country retreats. And since then there has always been this ambiguity in the defence of what is called nature and in its associated ideas of conservation [...] and the nature reserve. ${ }^{31}$

On this account, the destruction (exploitation/transformation) and 'conservation' of nature turn out to be mutually constitutive processes. The human and 'nature' separate conceptually in order to interact dialectically, ${ }^{32}$ resulting in a split between economy (oikos nomos) and ecology (oikos logos): 33 the law that applies to our dwelling seems to exist in opposition to the reason we dwell there at all. ${ }^{34}$

Returning to our present theme, then, it seems right to find the culmination of this process in the turn to a vocabulary of 'environment' over 'nature'. The notion of 'environment' already premises the non-identity of the human and 'nature' in a relational construct that renders the former (the human) active and the latter (the 'surroundings') passive and acted upon. But 'international environmental law' forgets-or rather suppresses - the complex history of the changing human understanding of nature. One key effect is to dehistoricise the relationship (environmental law textbooks, with some exceptions, habitually trace the origins of this body of law to the 1960s and 1970s), 35 instead characterising international environmental law as both novel and coextensive with an environmentalism of (largely) American provenance. ${ }^{36}$ Another effect is to relegate the adjudication of environmental law problems to the vagaries of science and economics.

\footnotetext{
${ }^{29}$ Williams (1980), 83.

30 Williams (1980), 84: 'we cannot afford to go on saying that a car is a product but a scrapyard a byproduct, any more than we can take the paint-fumes and petrol-fumes, the jams, the mobility, the motorway, the torn city centre, the assembly line [...] the strikes, as by-products rather than the real products they are.'

${ }^{31}$ Williams (1980), 81.

32 Adorno and Horkheimer (2002), 1, cite Francis Bacon: 'now we govern nature in opinions, but we are in thrall to her in necessity: but if we would be led by her in invention, we should command her by action.'

33 Williams (1980), 84: 'It will be ironic if one of the last forms of the separation between abstracted Man and abstracted Nature is an intellectual separation between economics and ecology.' See too Philippopolous-Mihalopolous (2011), 3.

34 Jean-Francois Lyotard (1993) cited in Coupe (2000), 135-38.

35 E.g., Birnie et al. (2009), 1: 'The development of modern international environmental law start[s] essentially in the 1960s.'

36 Notably Carson (1962).
} 


\section{ROMANTIC ROOTS OF INTERNATIONAL ENVIRONMENTAL LAW}

The romantic era matters to international environmental law both because key concepts underpinning this body of law were expressed by romantic writers during that period and because the expression of those concepts was both novel and essential to the romantic ésprit itself. Our aim here is not to follow the genealogy of specific environmental law formulae or principles, but rather to trace an overarching shift in the approach to the natural world that finds its first, deeply influential, articulation during that period, one which continues to reverberate through legal texts today.

Conventionally, the romantic movement refers to a loose grouping of artists, poets, and composers working in and around the revolutionary peaks of 1789 and 1848, united by a set of common themes and methodological presuppositions. ${ }^{37}$ While we will focus here on a subset of English-language poets, the larger context is transcontinental and multidisciplinary, a movement in which aesthetic compositions were conceived as political interventions at a time of social and ethical flux..$^{38}$ In this, the romantics were profoundly successful, at least insofar as they provided the fundamental premises of much later thought on the relation between the 'human' and 'nature' and a platform for powerful critiques of scientific and industrial activity from both right and left. ${ }^{39}$

Three hallmarks of romantic thought on nature have contributed to the contemporary constitution of international environmental law: the association of nature with the experience of (1) the aesthetic, (2) the authentic, and (3) the divine.

\section{The Aesthetic}

Writing against the enlightenment, ${ }^{40}$ the romantics pioneered the entirely novel idea that 'nature' has intrinsic value in its own right. Unlike their predecessors, the romantics regarded nature as an object of aesthetic sensibility, infused with beauty and meaning and inaugurating a higher state of human possibility. True, the advancing art of landscaping in the mid-eighteenth century displaced humanimposed symmetry and tree-lined avenues on the great estates with 'more natural' curves, clumps, lakes and inclines. ${ }^{41}$ However, even there the essential principle remained the desirability of 'improving' on that which is given-and it was just

\footnotetext{
${ }^{37}$ See generally Chandler in Chandler (2009). The romantic era may be dated back to 1770 and forward to the early twentieth century. Chandler (2009), 1; Siskin (2009).

${ }^{38}$ Chandler (2009), 1.

${ }^{39}$ Compare the Marxian embrace of the romantic analysis of human alienation from labour with the deep conservativism of late romantic figures such as W.B. Yeats, Paul de Man, and Martin Heidegger.

40 As William Blake (cryptically) put it: 'May God keep us from single vision and Newton's sleep.' Letter to Thomas Butt, 22 November 1802.

${ }^{41}$ Williams (2011), 122.
} 
this point that the romantics reversed. For the romantics, nature was the improver: it could not be improved upon, though it could be spoiled.

This familiar romantic love of nature-in-itself deserves a little scrutiny. Raymond Williams notes that it begins in awe-filled descriptions of the Alps shifting from (typically, in the 1600s) 'strange horrid and fearful crags and tracts' or 'ruins upon ruins in monstrous heaps' 42 to (Coleridge in 1802) 'motionless torrents [...] glorious as the Gates of Heaven beneath the keen full moon'. ${ }^{43}$ So in addition to the revision of the 'pastoral'-the old literary form representing tranquil human coexistence with nature ${ }^{44}$-in the hands of these 'nature poets' (itself a new term of art) and artists, there is the valorisation of something new: 'wilderness':

'Lo! The dwindled woods and meadows

What a vast abyss is there!'45

The admiration of nature in its own right was fundamental to the romantic ethos. For as Williams notes, ${ }^{46}$ what begins as a mere 'alteration of taste', an appreciation, among the discerning, for the 'picture-esque', was pushed in the hands of the romantics to become an entirely new sensibility—in Wordsworth's words:

$[\ldots]$ some new sense

Of exquisite regard for common things.

And all the earth was budding with these gifts

Of more refined humanity $[. . .]^{47}$

This new sensibility became also a normative source for a radical politics. By 'more refined humanity' is intended here both a humanity more attuned to nature and one whose own wilder nature has been tamed through a closer contact with 'nature'. Wordsworth is representative of a pronounced strain among the romantics foregrounding and lauding the 'lonely' or 'solitary' individual, whose self-understanding, arrived at through (purported) commune with nature, provides the basis for a broader and more egalitarian human community.48 So romantic egalitarianism would come to inform nineteenth century English radicalism (the push for greater social and civil rights culminating in an expanded franchise), which Wordsworth himself ultimately came to oppose. ${ }^{49}$

Meanwhile, 'the wild' as an object of beauty and awe was to have a particularly vibrant life in the United States, becoming - notably in the hands of

42 Williams (2011), 128, citing Christopher Hussey, The Picturesque: Studies in a Point of View (1927).

${ }_{43}$ Garrard (2012), 73.

${ }^{44}$ Such as John Clare's 'Pastoral Poesie' or Wordsworth's 'Michael', subtitled 'a pastoral poem'.

45 Wordsworth, 'To — On Her First Assent of the Summit Helvellyn'. Garrard (2012), 66-79.

46 Williams (2011), 129.

47 Wordsworth, The Prelude, Book XIV (added much later to the first 13 books of 1805).

48 See Williams (2011), 130-133. See Wordsworth's 'Michael', 'The Solitary Reaper', 'Lucy'.

${ }^{49}$ See, e.g., Coleridge and Southey (1969). 
the American romantic 'transcendentalists' Henry David Thoreau and Ralph Waldo Emerson - a more rugged experience than that of the English lake poets. It was a friend and disciple of Thoreau's, the Scottish immigrant John Muir, who would go on to found the Sierra Club in 1893, arguably the first environmental NGO, and still among the most influential. ${ }^{50}$

\section{The Authentic}

The romantics set themselves up against much that preceded them: eighteenth century poetry and art, science, industry, and of course aristocracy. In Wordsworth's 1802 preface to his and Coleridge's poetic manifesto, Lyrical Ballads, he spoke of 'tracing [...] the primary laws of our nature', by relating 'incidents and situations from common life [...] in [the] language really used by men; and at the same time to throw over them a certain colouring of imagination'. ${ }^{51}$ The 'Truth' (as he puts it elsewhere) is to be found in the ordinariness of 'low and rustic' subject matter. ${ }^{52}$ The solitary figure silhouetted against the landscape in total harmony with the materials and processes of his or her own labour is the authentic human. ${ }^{3}$ Wordsworth again:

$[\ldots]$ the sun and sky,

The elements, and seasons as they change,

Do find a worthy fellow-labourer there-

Man free, man working for himself, with choice

Of time, and place, and object $[\ldots]^{54}$

Implicit in the romantics, in contrast to this authentic existence, is the experience of alienation in the emergent urbanism of the late eighteenth century. ${ }^{55}$ One study on the romantics' sojourns in London-following Williams Godwin, Wordsworth and Blake, as well as Mary Wollstonecroft in the city—concludes that, 'London in the 1790s seems to produce, and be produced by, a new kind of metropolitan intellectual, marginalised by its economic and political divisions, alienated from its commercial values, wandering its chartered streets with a blank, or an appalled, sense of estrangement'. ${ }^{66}$ Here are the seeds of the romantic-inspired opposition to the industrial revolution, which continues as an 'environmentalist' undercurrent into the present.

\footnotetext{
50 Garrard (2009), 73-75.

51 Wordsworth (2000), 596-597.

52 Wordsworth (2000), 596.

53 Above note 47. Also John Clare's rustic figures, and, in landscape painting, John Sell Cotman's 1831

'The Shepherd on the Hill', Caspar David Friedrich's 1810 'Wanderer Above the Sea of Mist'.

54 Wordsworth, The Prelude, Book VIII.

55 William Morris, 'Art and Socialism' (1884) makes the point explicit.

56 Barrell (2012), 158. See, e.g., William Blake's Preface to Milton, also known as Jerusalem, contrasting London's 'dark satanic mills' to 'England's green and pleasant land'.
} 


\section{THe Divine}

In a related vein, the twentieth century German philosopher Martin Heidegger too located the experience of the authentic in the romantics, in his celebrated essay 'Poetically Man Dwells'. The essay takes a prose poem attributed to Friedrich Hölderlin, 'In Lovely Blue', as the starting point for a meditation on the human relation to 'home', combining a familiar romantic brew of art, nature, and transcendence, to identify the 'basic character of human existence', dwelling 'poetically' 'on this earth'. ${ }^{57}$

Hölderlin's poem is concerned with how the human may 'measure' itself against the divine: which becomes possible, he says, through being rooted on earth yet capable of sizing up the heavens and stars. Indeed, a quasi-pantheism of this sort is common among the romantics in response to the burgeoning atheism of the enlightenment. Wordsworth again provides a good example:

But list! a voice is near;

Great Pan himself low-whispering through the reeds,

"Be thankful, thou; for, if unholy deeds

Ravage the world, tranquillity is here!"58

The poem is written during the Napoleonic wars, and Wordsworth finds an allegory for transcendent peace beyond human concerns. Nature is, as God had been, beyond the fray, timeless, still (that is, returning to balance in time, an idea that translates today into the notion of 'ecosystem'). The same sentiment runs through John Clare's 1824 'The Eternity of Nature'. ${ }^{99}$ Earthly peace is attainable through a deeper and more imaginative human engagement with the natural order. This is, of course, an ambition we will come to associate broadly with international law.

But it is not merely that God is or resides in nature. It is rather that the experience of the divine is locatable only through imaginative immersion in the natural world. The experience of divinity dwells in the imaginative creativity of the poet in correspondence with nature writ large. W.B. Yeats, the self-styled 'last romantic' captured the point precisely in his musings on William Blake, who wrote a hundred years before him:

[Blake] had learned [...] that imagination was the first emanation of divinity $[\ldots]$ and that the sympathy with all living things [is what] the imaginative arts [must] awaken... He cried again and again that every thing that lives is holy, and that nothing is unholy except things that do not live-lethargies, and cruelties, and timidities, and denial of imagination. ${ }^{60}$

\footnotetext{
${ }^{57}$ Heidegger (2001), 215.

58 Wordsworth, 'Composed by the Side of Grasmere Lake' (1806).

${ }^{59}$ John Clare, 'The Eternity of Nature' (1824) in Clare (1965).

${ }^{60}$ Yeats (2007), 84.
} 
The enthronement of a certain kind of imagination was, for the romantics, central to accessing the 'essential' truth behind superficial appearances. Fixed and mechanised, nature in enlightenment science was dead or asleep under the microscope. Observation informed by imagination yielded a truer, more authentic, experience of life: the 'primary' laws of nature, life infused with divinity. But wilfully investing 'nature' with 'imagination', as Blake recommended, is inherently problematic: the risk is that the self becomes sole arbiter of the 'authentic'. This is the essence of Walter Ruskin's famous charge of the 'pathetic fallacy': that ultimately 'nature itself is displaced by a symbolic and, paradoxically, anthropocentric will. ${ }^{61}$

This story of the romantic imagination is relevant to our present inquiry for two reasons. First, it is a reminder that, despite regular rhetorical hewing to the 'real', to nature itself, the romantics cultivated a decidedly shaky materialism. 'Nature itself turns out to owe everything to the imaginative authorial voice pronouncing upon it. So where international environmental law prizes the 'intrinsic value of nature', the 'nature' in question will often turn out to be vague or unlocatable. The second point is that the romantic development, from Wordsworth to Yeats, tends increasingly to fasten the lone authorial voice to an imaginative didacticism, itself centred on a community steeped in a landscape with nostalgic Volk-ish contours. The pronounced conservativism that marks the later Wordsworth develops into deliberate elitism in Yeats (the 'last romantic') and flirts with full-blown authoritarianism in Heidegger-arch-philosopher of the 'authentic'. The imaginative dismissal of the human in much environmentalism may, in short, lend itself to dictatorial law, as indeed happened in 1930s Germany. ${ }^{62}$

In the romantics, then, there is a clearly dialectical move- the 'human', now quite apart from 'nature', adopts the position of audience or commentator, andthrough a new appreciation and awe of this (wild, inspiring, motivating) nature-is reformed as a 'human' once again in touch' with the natural world. ${ }^{63}$ This combination — of a human distinct from her surroundings, entailing a dynamic and politically transformative relationship with the natural world both for its intrinsic value and for the broader good it renders humanity, carries into the key documents of international environmental law in preambular language such as the following:

Man is both creature and moulder of his environment, which gives him physical sustenance and affords him the opportunity for intellectual, moral, social and spiritual growth. [...] (Stockholm Declaration, 1971)

${ }^{61}$ Ruskin in Coupe, ed., (2000), 26.

62 Giddens (2008), 51-2; Brüggemeier et al. (2005). On Heidegger's place in modern environmentalism, see, e.g., Röhkramer (2005); Garrard (2000), 34-36.

63 On the human as 'audience' for the natural world, see Adorno and Horkheimer (2002), 27. 
[1] view of the magnitude and gravity of the new dangers threatening them, it is incumbent on the international community as a whole to participate in the protection of the cultural and natural heritage of outstanding universal value. (UNESCO Convention, 1972)

The Contracting Parties [...] Conscious of the intrinsic value of biological diversity $[\ldots]$ and of the $[. .$.$] educational, cultural, recreational and aesthetic values of$ biological diversity and its components. (CBD, 1992)

These invocations incorporate each of our observations above: the aesthetic and educational value of nature providing housing for an authentic human life, imbued with faith and spiritual growth.

\section{THE COLONIAL ORIGINS OF INTERNATIONAL ENVIRONMENTAL LAW}

European colonialism was premised on the exploitation of natural resources and on the maintenance of conditions of global trade in raw materials. This was done in a context of tacit and at times explicit agreement between a small group of 'Powers'. In fact, colonial era discoveries of 'new worlds' and new natural resources were reshaping thinking and writing on nature long before the romantics. The rise of the botanical garden epitomised two colonial drives: a scientist (naturalist) fascination with discovered 'paradises' and the pragmatic desire to capitalise on this novelty, by cultivating and commercialising seeds and species beyond their native lands.

There are many examples of international environmental law's colonial origins. Take, for example, the 1900 International Convention on the Conservation of Wild Animals, Birds and Fish in Africa ${ }^{64}$-negotiated as the full consequences of the frenzied extermination of animal populations perpetrated by Europe's hunting classes throughout the nineteenth century became apparent. ${ }^{65}$ The Convention was itself largely negotiated by hunters; it provides a set of rules, categorising animals into five schedules: some (the near extinct, such as whitetailed gnu) were no longer to be hunted, others were killable on sight ('dangerous' vermin, extending to lions and leopards), the remainder under certain conditions. ${ }^{66}$ The Convention imagined immense nature 'reserves' or parks, parts of which would be off-bounds altogether, allowing animal stocks to replenish, other areas to be off-bounds to indigenous populations, allowing hunters to stalk animals 'in the wild'. The Convention's most obvious descendent today is the Convention on the

64 This paragraph relies in the main on Cioc (2009), ch.4 and MacKenzie (1988), ch.8.

65 MacKenzie (1988), 123-128.

66 The Convention never came into force although its principal terms were applied by Britain and Germany. 
International Trade in Endangered Species, which mimics its aspirations, its schedules and its calibration of killability.

In what follows, we confine ourselves to two representative moments of colonial activity, which we take from the eighteenth and twentieth centuries respectively. These provide examples of, in the first case, a policy response to observed environmental degradation, and, in the second, broad colonial economic policies in prototypical conformity with the contemporary notion of 'sustainable development'.

\section{Environmental Degradation in the Early Colonial Period}

In his seminal work, Green Imperialism, the first systematic account of the origins of environmentalism in the colonial experience, Richard Grove devotes considerable space to island colonies such as Barbados, St Helena, and Mauritius. ${ }^{67}$ Due to their relatively small size, he argues, the direct environmental impact of colonialsupported land practices became evident, and it was also possible to experiment with (legal) correctives. By the mid-1660s much of Europe was in the grip of a timber crisis, largely due to extensive shipbuilding, itself associated with colonial expansion and competition. One response was to attempt to limit deforestation at home, although in England these efforts often met with sufficient opposition in the form of entrenched rights and popular resistance to fail. ${ }^{68}$ Another was to redirect supply abroad, treating 'countries yet barbarous as the right and proper nurseries' for the supply of timber. ${ }^{69}$ Cutting down forests in the colonies brought other advantages too: land denuded of forests could be turned over to plantations and other uses, and, until the late 1700s, was considered both healthier and more sightly than untamed woods. ${ }^{70}$

Although the possibility that deforestation may affect the wider environment—by, for example, altering rainfall patterns—had been flagged as early as the fifteenth century, it was only in the eighteenth century that such effects were systematically observed and recorded on islands such as St Helena and Mauritius. In 1708, the then governor of St Helena, John Roberts of the East India Company, became worried that 'the island in 20 years time will be utterly ruined for want of wood'. ${ }^{71}$ Over the next 80 years, successive governors raised concerns with the East India Company Directors in London over increasingly evident environmental problems such as drought, floods, and soil erosion. ${ }^{72}$ They attempted to slow the pace of deforestation, notably with a St Helena Forest Act of

\footnotetext{
${ }^{67}$ Grove (1995).

${ }^{68}$ Grove (1995), 57. For example, the Dean Forest Act 1657 and New Forest Act 1697.

${ }^{69}$ Dr Thomas Preston, quoted in Grove, 56.

${ }^{70}$ Grove (1995), 65-67.

71 Grove (1995), 112; 109-115.

${ }^{72}$ Grove (1995), 121-122.
} 
1731, mandating the 'destruction' of a portion of the island's many wild goats..$^{73}$ Their efforts were, however, frustrated by the Company Directors until 1794, when the Directors, in a sudden volta face, directed the then governor, Rupert Brooke, to commence a reafforestation programme, since it is well known that trees have an attractive power on the clouds, especially when they pass over hills so high as those on your island'. ${ }^{74}$ Otherwise, the Directors were later to warn, 'the present inhabitants will afford their posterity as just a reason for condemning their conduct as they have now to deplore that of their ancestors'. ${ }^{75}$

Of course, timber shortages and proprietary tussles over land use had underpinned forestry legislation and centrally organised tree-planting long before 1794. The specific innovations captured here, however, are: the added cognizance of what we would today refer to as 'environmental degradation'; an acceptance of human impact upon the environment; and the appeal, with the Company Directors echoing Roberts across the years, to 'posterity', a clear forebear of the regular invocation of 'future generations' that runs through much contemporary international environmental law. ${ }^{76}$

The Company's sudden u-turn owed much to a 'sea-change' in climate science orthodoxy in the mid-eighteenth century-which Grove attributes in particular to the English scientist Stephen Hales, a leading figure in both the French Académie des Sciences and the English Society of Arts. ${ }^{77}$ Key evidence for Hales' speculations on the human capacity to alter the atmosphere was found in small island colonies such as St Helena and (in the event) Mauritius. A catalytic figure was Pierre Poivre, a naturalist, physiocrat, botanist, and administrator (for the French East India Company) of Mauritius, who, having developed a theory linking deforestation to rainfall patterns, introduced regulations on that basis in Mauritius in $1769 .{ }^{78}$ On Grove's meticulously researched account, Poivre's work 'laid the foundation [...] for the forest protection policies [subsequently] set up in both French and British colonial island territories. These early policies became the direct forerunners and models for almost all later colonial forest-protection policies. ${ }^{79}$

For reasons not dissimilar to the failure of seventeenth Century English forest laws, international agreement on forestry management remains elusive. 80 The essential point of this story is broader however: colonial forest-protection laws identify 'ecosystems'-loci of 'natural balance' which, if overexploited, may

\footnotetext{
${ }^{73}$ Grove (1995), 120-124.

${ }^{74}$ Grove (1995), 124, citing Council of Directors to Governor, 7 March 1794 in H.R, Janisch (ed.), Extracts from the St Helena records and chronicles of Cape commanders, Jamestown, St Helena (1908).

${ }^{75}$ Grove (1995), 124, citing Council of Directors to Governor, 25 March 1795 in Janisch (ed.).

76 See, for example, Espoo Convention, Aarhus Convention, UNFCCC, CBD, and 'sustainable development' as usually defined.

77 Grove, 164.

${ }^{78}$ Grove provides a full account of deforestation and climatic change in Mauritius, and Poivre's response, 179-222.

${ }^{79}$ Grove, 166.

${ }^{80}$ See above, note 5; see also REDD+, available at http://unfccc.int/methods/redd/items/7377.php, last accessed on 27 January 2014.
} 
be destroyed, contaminating a range of resources and ultimately damaging the wider economy. ${ }^{81}$

\section{Sustainable Development in the late Colonial Period}

For a second example, we have chosen the increasingly refined practices of species and crop management that developed across the British Empire from the late nineteenth century through decolonisation, amounting to de facto templates of 'sustainable development', perhaps the foremost principle of international environmental law today - which seeks that 'development' should proceed so as to ensure that 'the needs of current generations are met without compromising the needs of future generations'-but pre-empting the latter term, popularised by the 1987 Brundtland Commission, by some considerable time. ${ }^{82}$

The case for early colonial practices of sustainable development builds on the evolution of practices over generations of colonial rule. Increasingly concerned with optimising value in the colonies, by the late 1800s, annual reports to the Colonial Office (CO) followed a regimented template: finances, 'trade, agriculture and industry', climate; legislation, judicial statistics ${ }^{83}$-later extending also to health, natural resources, labour, wages, banking. ${ }^{84}$ The point was to locate the comparative advantage of each territory (given climatic and other factors), and to generate an enabling environment for effective specialisation in export commodities. With few trade barriers across British governed spaces, each territory could export to the Empire as a whole and use the resulting income to buy imports from other colonial places. ${ }^{85}$ In a virtuous circle, the Empire economy would grow as each territory developed.

This empire of free trade was not entirely, however, a free market. Especially after 1885, the metropolitan centre was not beyond giving the market firm guidance, ${ }^{86}$ steering countries towards their comparative advantage and generating demand for territorial specialities (through an 'Empire Marketing Board'). From the early twentieth century, fact-finding missions were undertaken to determine whether individual colonies were optimally positioned within the wider economy,

\footnotetext{
81 See, for example, the Convention for the Protection of the Marine Environment of the North-East Atlantic (OSPAR Convention), or the many conventions overseen by the International Maritime Organization, available at IMO: www.imo.org/About/Conventions/ListOfConventions/, last accessed on 27 January 2014.

82 Brundtland Report (1987).

${ }^{83}$ Colonial Reports-Annual, Nos 260, 271, 346, 353, 381, 405, 409, 472, 633, 695, 773, 881, 1079, 1122 , 1207, 1410. Of these Nos 260 and 346 (both written by Frederick Lugard and dealing with Northern Nigeria) do not follow the template. Elsewhere, however by 1898, the template was already in use (see No. 271 on the Gold Coast); it was universalised by the early 1900s.

${ }^{84}$ Colonial Reports-Annual, Nos. 1657, 1904.

85 This assessment derives from a close reading of Colonial Office annual reports, by territory, from the late 1890s, through to the late 1930s. On the related question of the British Empire approach to (international) trade, see Gallagher and Robinson (1953), and the ensuing discussion in Louis (1976); also Howe (2007), 41.

${ }^{86}$ Howe (2007).
} 
to recommend steps that might be taken to consolidate their position and, if needed, to reorient economies towards new products. The resulting reports evince a consistent interest in long-term sustainability: these were significant investments and they were intended to pay out over generations. However, once the prospect of decolonisation appeared on the horizon, the need for establishing a lasting basis for colonial economies became even more pressing.

A series of Colonial Office reports appear from the 1920s through to the 1950s, the period when centrally-dictated management of colonial economies reached its zenith and began its decline. For present purposes, what stands out in these reports is the degree to which they demonstrate a consistent concern for creating the conditions for long-term sustainability of the industries in question. A report on 'The Production of Fish in the Colonial Empire', which we will take as our example, proceeds territory by territory to document the kinds of fish produced (caught, processed, and readied for sale) in each one. ${ }^{87}$ For each territory-from West Africa to Far East Asia-the report traces the proactive steps taken by colonial governments to place fish production on a stable footing and to expand it. Accounts are provided of the amount of fish caught, sold in local markets and exports, the sophistication of fishing and processing technologies; the existence or establishment of research centres monitoring fish stocks; the existence, mandate and competence of authorities (Fisheries 'Departments', 'Officers', 'Surveys'); the training available to relevant officials; and-perhaps most intriguingly from the present perspective - the possibilities of fish-farming. ${ }^{88}$

So a follow-up 1953 report notes that, 'while the development of fisheries is a matter for each individual territory', 'fisheries research is organised on a regional basis, since groups of territories (e.g., East Africa, West Africa, Malaysia) tend to have the same fundamental problems' ${ }^{89}$ Core-funded regional fish centres employed geneticists, 'in view of the importance of this work and its long-term character'. ${ }^{90}$ In Kenya, a 'fish culture experimental farm' was started to 'obtain accurate data' of fish yields and to determine the 'life history' of two 'most promising species' in order 'to control the breeding of mosquitoes and snails, which are responsible respectively for malaria and bilharzia'.91 In Malaya, 'wherever new land has been brought under controlled irrigation for rice cultivation, provision for fish cultivation has been made. ${ }^{92}$ As a result of 'demonstrations, instructional pamphlets, and financial loans', more than 1,800 'new fish cultivators' had begun to reap a harvest and by 1952, there were ' 450,000 acres of irrigated padi [sic] land producing fish as a catch crop [sic]'. Moreover, 'a new form of fish farming, combined with pig raising has been devised under the supervision and guidance of the Fisheries Department', such that 'the production

\footnotetext{
${ }^{87}$ Colonial Office (1949).

${ }^{88}$ Colonial Office (1949), 8-14.

${ }^{89}$ Colonial Office (1954), 5.

${ }^{90}$ Colonial Office (1954), 5.

${ }^{91}$ Colonial Office (1954), 15.

${ }^{92}$ Colonial Office (1954), 19.
} 
of fruit, pigs and vegetables is integrated with the production of fish, resulting in economy of man-power, land and raw materials'. ${ }^{93}$

Sustainable development is not an easily applied principle-indeed, such is its inherent vagueness that it may actually be unhelpful in determining policy. ${ }^{94}$ Nevertheless, where sustainability is sought or claimed in practice to have been achieved, it is through systematic long-term anticipatory action-monitoring, substituting, and proactively replenishing stocks and encouraging linkage between different kinds of food production (fish, rice) and other sectoral issues such as health (malaria, bilharzia). Of many available examples of such practices in the colonial period, we choose fish, precisely because fisheries today generally exemplify unsustainable practice par excellence. ${ }^{95}$

\section{CONCLUSION}

This theoretical account identifies the historical forerunners of international environmental law in order to clarify two dominant and competing imperatives that drive it. In our sketch we have shown how the broad impetus underlying international environmental law-its principal motivating force-derives from a particular understanding of the human-natural relation that is directly traceable to European romanticism. A newly aestheticised experience of the natural world gave rise to highly specific notions of an authentic human experience of nature and of the divine. We have shown how a romantic sensibility mobilised certain ideas that later find expression in international environmental law. We have indicated how the particularity of this vision underpins preambular language in core international environmental law texts. But its lasting power remains unarticulated, in the promise, hope, and faith invested in the leading principles of international environmental law.

The romantics present the non-human world as inherently valuable; essential to a version of human good life that conceives of well-being in a manner that may be described as 'ecological': responsive to and respectful of the logos of 'home'. This imperative reappears throughout environmental movements of the twentieth century, in the direct action of Sea Shepherd, in 'deep ecology', in 'pachamama' earth rights movements. And of course the vision driving these groups is also romantic in a second sense of the term, in that it brooks little or no compromise with other competing imperatives.

\footnotetext{
93 Colonial Office (1954), 19.

${ }^{94}$ E.g., Giddens (2008), 59-63. The hard questions are 'develop what', 'for how long' and 'for whom'? See Kates et al. (2005).

95 E.g., World Bank Global Program on Fisheries, available at http://go.worldbank.org/0I0GPE15Y0, last accessed on 27 January 2014.
} 
International environmental law is clearly not exhausted by this romantic vision. The second strong lineage we locate derives from practice-the longstanding management of natural resources developed through the colonial era. Colonial practices and conventions are not the only precursors of environmental management, of course-but they are arguably the most relevant to international environmental law precisely because they are constructed within a transnational context, viewing natural resources in terms of global production and demand, and managing them within a context of international trade.

Our first example highlights how colonial rule inaugurated and consolidated an administrative capacity for observing and responding to environmental degradation, the threat of loss due to secondary effects (foreshadowing toxic pollution, climate change). Our second example shows colonial authorities positioned over time to understand resource production and consumption within the broadest global context and instituting long-term sustainable management practices for the replenishment and substitutability of stocks. 96

On our reading, then, it is no accident that the rise of contemporary international environmental law coincides with the decolonisation period of the 1960s and 1970s. The end of colonialism involved the dismantling of a key coordinating mechanism that had maintained and oiled the global movement of primary commodities and resources, and provided the rationale for a network of conservation areas. When global resource management moved into an 'international' domain, as the end of colonialism signalled, it is unsurprising that a body of law should have come into being to manage the exploitation of resources at the margins and their potential defilement through uncontrolled pollution.

In short, romanticism and colonialism constitute two imperatives, each nonnegotiable in its own way. Each of these imperatives can be seen at work through the key international environmental law principles and treaties. In each case, the promise to respect an inherent bound within 'nature itself is destabilised by the necessity of exploiting, developing, applying the non-human as a 'resource'. And whereas this body of law and principles is generally portrayed as mediating these competing demands, our analysis demonstrates the extraordinary difficulty of achieving any such mediation. For at bottom, these are not reconcilable views: what one holds sacred, the other profanes.

This is not to imply that international environmental law serves no function. Assuredly it does: it is the locus for the recognition of the sacred in the nonhuman world, and the occasion for its profanation, in full view, as it were. International environmental law publicly enacts the profanation of the thing it has designated as sacred. As a result, this body of law can appear improbably elastic, providing a framework for the ongoing (if occasionally attenuated) destruction and commodification of natural phenomena in a language of care and protection.

96 This insistence on 'development' carries from the colonial into the postcolonial era and into international environmental law's constitutive developmentalism. E.g., Rio Declaration, Stockholm Declaration, UNCCD, UNFCCC. 
International environmental law, then, is a principal locus for the dynamic Raymond Williams remarked 40 years ago: a world split into an upwind of preservation and recreation and a downwind of waste and destruction, a pastoral idyll and a dump. International environmental law excoriates the dump, the waste, the loss of life and species-but it is not equipped to halt it, for 'a storm is blowing from Paradise [and] this storm is what we call progress'. ${ }^{97}$

${ }^{97}$ Benjamin (1967), 257-8. 


\section{REFERENCES}

\section{BOOKS, CHAPTERS, AND ARTICLES}

Theodor Adorno and Max Horkheimer, Dialectic of the Enlightenment (Stanford UP, 2002)

John Barrell, 'London in the 1790s' in Chandler, ed. (2009)

Jonathan Bate, Romantic Ecology: Wordsworth and the Environmental Tradition (Routledge, 1991)

William Beinart and Lotte Hughes, eds, Environment and Empire (Oxford UP, 2007)

Walter Benjamin, 'Theses on the Philosophy of History', in Benjamin, Illuminations, [Trans. Harry Zohn] Schocken Books (1967 [1955])

Patricia Birnie, Alan Boyle, and Catherine Redgewell, International Law and the Environment, 3rd edition (Oxford UP, 2009)

Edith Brown Weiss, In Fairness to Future Generations (UN University, 1989)

Franz-Josef Brüggemeier, Mark Cioc, and Thomas Zeller, eds, How Green Were the Nazis? (Ohio UP, 2005)

Lawrence Buell, The Environmental Imagination: Thoreau, Nature Writing and the Formation of American Culture (Princeton UP, 1995)

Rachel Carson, Silent Spring (Penguin Classics, 2012 [1962])

James Chandler, 'Introduction' in Chandler, ed., (2009)

James Chandler, ed., The Cambridge History of English Romantic Literature (Cambridge UP, 2009)

Mark Cioc, 'Hunting, Agriculture, and the Quest for International Wildlife Conservation during the Early Twentieth Century' in Cioc, The Game of Conservation (Swallow Press, 2009)

John Clare, Selected Poems (Everyman, 1965)

Laurence Coupe, ed., The Green Studies Reader: From Romanticism to Ecocriticism (Routledge, 2000) 
Sean Coyle and Karen Morrow, Philosophical Foundations of Environmental Law (Hart, 2004)

Alfred W. Crosby, Ecological Imperialism: The Biological Expansion of Europe, 900-1900 (Cambridge UP, 1986)

John Gallagher and Ronald Robinson, 'The Imperialism of Free Trade', 6 The Economic History Review (1953) 1

Greg Garrard, Ecocriticism (Routledge, 2012)

Anthony Giddens, The Politics of Climate Change (Polity Press, 2009)

Hugo Grotius, De Iure Belli ac Pacis, 3 vols (Liberty Fund, 2005 [1625])

Richard Grove, Green Imperialism: Colonial Expansion, Tropical Island Edens and the Origins of Environmentalism, 1600-1800 (Cambridge UP, 1995)

Matthew Hale, The Primitive Organisation of Mankind Considered and Examined According to the Light of Nature (William Godbid, 1677)

Martin Heidegger, 'Poetically Man Dwells' in Heidegger, Poetry, Language, Thought (Perennial Classics, 2001 [1953])

Thomas Hobbes, Leviathan (Gutenberg Press, 2009 [1651])

Anthony Howe, 'Free Trade and Global Order: the Rise and Fall of a Victorian Vision', in Duncan Bell, ed., Victorian Visions of Global Order: Empire and International Relations in Nineteenth-Century Political Thought (Cambridge UP, 2007)

Stephen Humphreys, Theatre of the Rule of Law (Cambridge UP, 2010)

Kevin Hutchings, Romantic Ecologies and Colonial Cultures in the British-Atlantic World 1770-1850 (MQUP, 2009)

Robert W. Kates, Thomas M. Parris, and Anthony A. Leiserowitz, 'What is Sustainable Development: Goals, Indicators, Values and Practice', Environment: Science and Policy for Sustainable Development 47 no.3 (April 2005) 8-21

William Roger Louis, ed., Imperialism: The Robinson and Gallagher Controversy (New Viewpoints, 1976). 
Jean-Francois Lyotard, Political Writings (University of Minnesota Press, 1993)

John MacKenzie, The Empire of Nature (Manchester UP, 1988)

Max Oelschlager, The Idea of Wilderness: From Prehistory to the Age of Ecology (Yale UP, 1993)

Oxford English Dictionary, $3^{\text {rd }}$ ed. (2011), online at: http://www.oed.com/view/Entry/63089

Andreas Philippopolous-Mihalopolous, ed., Law and Ecology: New Environmental Foundations (Routledge, 2011)

Andreas Philippopolous-Mihalopolous, 'Introduction' in PhilippopolousMihalopolous, ed. (2011)

Martha Roggenkamp, Catherine Redgwell, Anita Rønne, and Iñigo del Guayo, eds, Energy Law in Europe: National, EU and International Regulation, 2nd edn (Oxford UP, 2007)

Thomas Röhkramer, 'Martin Heidegger, National Socialism and Environmentalism' in Brüggemeier et al., eds (2005)

John Ruskin, Modern Painters, in Laurence Coupe, ed., The Green Studies Reader: From Romanticism to Ecocriticism, (Routledge, 2000)

Philippe Sands and Jacqueline Peel, Principles of International Environmental Law, 3rd edition (Cambridge UP, 2012)

Clifford Siskin, 'The Problem of Periodization: Enlightenment, Romanticism, and the Fate of System', in Chandler, ed. (2009)

Samuel Taylor Coleridge and Robert Southey, Omniana (Centaur Classics, 1969 [1808])

Keith Thomas, Man and the Natural World: Changing Attitudes in England 1500-1800 (Penguin, 1983)

Peter Thorsheim, Inventing Pollution: Coal, Smoke, and Culture in Britain since 1800 (Ohio UP, 2006)

Richard Tuck, Natural Rights Theories: Their Origin and Development (Cambridge UP, 1979) 
Alexandra Walsham, The Reformation of the Landscape: Religion, Identity and Memory in Early Modern Britain and Ireland (Cambridge UP, 2011)

Raymond Williams, 'Ideas of Nature' in Williams, Problems in Materialism and Culture (Verso, 1980 [1972])

Raymond Williams, The Country and The City (Spokesman, 2011 [1973])

William Wordsworth, The Major Works (Oxford World Classics, 2000)

W.B. Yeats, 'William Blake and the Imagination', in The Collected Works of W.B. Yeats, Vol. IV: Early Essays (Scribner, 2007 [1897])

\section{REPORTS}

A/RES/42/187, Report of the World Commission on Environment and Development: Our Common Future (11 December 1987) (Brundtland Report)

Colonial Office, The Production of Fish in the Colonial Empire (HMSO, 1949), Colonial No. 237

Colonial Office, The Production of Fish in the Colonial Empire (Revised Edition) (HMSO, 1954), Colonial No. 300

Colonial Reports-Annual, No. 260, Niger. West African Frontier Force, Reports for 1897-8 (HMSO, 1899)

Colonial Reports-Annual, No. 271, Gold Coast, Report for 1898 (HMSO, 1899)

Colonial Reports-Annual, No. 346, Northern Nigeria, Report for the period from $1^{\text {st }}$ January, 1900, to $31^{\text {st }}$ March, 1901, by The High Commissioner of Northern Nigeria, Brigadier-General Sir F. Lugard K.C.M.G., C.B., D.S.O. (HMSO, 1902)

Colonial Reports-Annual, No. 353, Southern Nigeria, Report for 1900 (HMSO, 1902)

Colonial Reports-Annual, No. 381, Southern Nigeria, Report for 1901 (HMSO, 1902)

Colonial Reports-Annual, No. 405, Southern Nigeria, Report for 1902 (HMSO, 1903) 
Colonial Reports-Annual, No. 409, Northern Nigeria, Report for 1902 (HMSO, 1903)

Colonial Reports-Annual, No. 472, British Central Africa Protectorate, Report for 1904-5 (HMSO, 1906)

Colonial Reports-Annual, No. 633, Northern Nigeria, Report for 1908-9 (HMSO, 1910)

Colonial Reports-Annual, No. 695, Southern Nigeria, Report for 1910 (HMSO, 1911)

Colonial Reports-Annual, No. 773, Bechuanaland Protectorate, Report for 19123 (HMSO, 1914)

Colonial Reports-Annual, No. 881, East Africa Protectorate, Report for 1914-5 (HMSO, 1916)

Colonial Reports-Annual, No. 1079, Uganda, Report for 1919-20 (HMSO, 1921)

Colonial Reports-Annual, No. 1122, Colony and Protectorate of Kenya, Report for 1921-2 (HMSO, 1922)

Colonial Reports-Annual, No. 1207, Gold Coast, Report for 1922-23 (HMSO, 1924)

Colonial Reports-Annual, No. 1410, Northern Rhodesia, Report for 1927 (HMSO, 1928)

Colonial Reports-Annual, No. 1657, Annual Report on the Social and Economic Progress of the People of the Gold Coast, 1932-33 (HMSO, 1934)

Colonial Reports-Annual, No. 1904, Annual Report on the Social and Economic Progress of the People of Nigeria, 1938 (HMSO, 1939)

\section{TREATIES}

Stockholm Declaration on the Human Environment, 1971 (Stockholm Declaration) 
UNESCO Convention Concerning the Protection of the World Cultural and Natural Heritage (World Heritage Convention) (Paris, 16 November 1972, 1037 UNTS 151)

Convention on the Prevention of Marine Pollution by Dumping of Wastes and Other Matter (London Convention) (London, 29 December 1972, 1046 UNTS 120)

Convention on International Trade in Endangered Species of Wild Flora and Fauna (CITES) (Washington D.C., 3 March 1973, 993 UNTS 243)

UNECE Convention on Long-Range Transboundary Air Pollution (CLRTAP) (Geneva, 13 November 1979, 1302 UNTS 217)

Basel Convention on the Control of Transboundary Movements of Hazardous Wastes and Their Disposal (Basel Convention) (Basel, 22 March 1989, 1673 UNTS 57)

Convention on Environmental Impact Assessment in a Transboundary Context (Espoo Convention) (Espoo, 25 February 1991, 1989 UNTS 309)

Rio Declaration on Environment and Development, 1992 (Rio Declaration)

United Nations Framework Convention on Climate Change (UNFCCC) (New York, 9 May 1992, 1771 UNTS 107)

Convention on Biological Diversity (CBD) (Rio de Janeiro, 5 June 1992, 1760 UNTS 79)

United Nations Convention to Combat Desertification (UNCCD) (Paris, 14 October 1994, 1954 UNTS 3)

UNECE Convention on Access to Information, Public Participation in Decisionmaking and Access to Justice in Environmental Matters (Aarhus Convention) (Aarhus, 25 June 1998, 2161 UNTS 447)

International Tropical Timber Agreement (ITTA) (Geneva, 27 January 2006, Doc. TD/TIMBER.3/12) 


\section{Cases}

\section{World Trade Organization Dispute Settlement Body}

Appellate Body Report, United States - Standards for Reformulated and Conventional Gasoline, WT/DS2/AB/R, adopted 20 May 1996, DSR 1996:I, 3 (US_Gasoline)

Appellate Body Report, EC Measures Concerning Meat and Meat Products (Hormones), WT/DS26/AB/R, WT/DS48/AB/R, adopted 13 February 1998, DSR 1998:I, 135 (EC-Hormones)

Appellate Body Report, United States - Import Prohibition of Certain Shrimp and Shrimp Products, WT/DS58/AB/R, adopted 6 November 1998, DSR 1998:VII, 2755 (US—Shrimp)

Appellate Body Report, Canada - Certain Measures Affecting the Automotive Industry, WT/DS139/AB/R, WT/DS142/AB/R, adopted 19 June 2000, DSR 2000:VI, 2995 (Canada-Autos)

Appellate Body Report, European Communities - Measures Affecting Asbestos and Asbestos-Containing Products, WT/DS135/AB/R, adopted 5 April 2001, DSR 2001:VII, 3243 (EC-Asbestos)

Panel Reports, European Communities - Measures Affecting the Approval and Marketing of Biotech Products, WT/DS291/R / WT/DS292/R / WT/DS293/R, Add.1 to Add.9, and Corr.1, adopted 21 November 2006, DSR 2006:III, 847 (EC-Biotech)

Appellate Body Report, Brazil - Measures Affecting Imports of Retreaded Tyres, WT/DS332/AB/R, adopted 17 December 2007, DSR 2007:IV, 1527 (BrazilRetreaded Tyres)

\section{European Court of Human Rights}

López. Ostra v. Spain, Application no. 16798/90, Judgment of 9 December 1994

Öneryzldı乏v. Turkey, Application no. 48939/99, Judgment of 30 November 2004

Fadeyeva v. Russia, Application no. 55723/00, Judgment of 9 June 2005

Budayeva v. Russia, Applications nos. 15339/02, 21166/02, 20058/02, 11673/02 and 15343/02, Judgment of 20 March 2008 


\section{International Court of Justice}

Case Concerning Gabčikovo-Nagymaros Project (Hungary/Slovakia) ICJ Judgment of 25 September 1997, ICJ Rep. 1997, 7 (Gabcilkovo-Nagymaros)

Case Concerning Pulp Mills on the River Uruguay (Argentina v. Uruguay), ICJ Judgment of 20 April 2010, I.C.J. Reports 2010, 14 (Pulp Mills)

\section{Other}

Trail Smelter Arbitration (United States v. Canada) 1941, U.N. Rep. Int'l Arb. AW ARDS 1905 (1949) 